\title{
Serologic Evidence for Influenza C and D Virus among Ruminants and Camelids, Africa, 1991-2015
}

\author{
Elias Salem, Elizabeth A.J. Cook, \\ Hicham Ait Lbacha, Justine Oliva, Félix Awoume, \\ Gilbert L. Aplogan, Emmanuel Couacy Hymann, \\ Dishon Muloi, Sharon L. Deem, Said Alali, \\ Zaid Zouagui, Eric M. Fèvre, Gilles Meyer, \\ Mariette F. Ducatez
}

Influenza D virus has been identified in America, Europe, and Asia. We detected influenza D virus antibodies in cattle and small ruminants from North (Morocco) and West (Togo and Benin) Africa. Dromedary camels in Kenya harbored influenza $C$ or $D$ virus antibodies, indicating a potential new host for these viruses.

$\mathrm{I}^{\mathrm{n}}$ nfluenza D virus (IDV) was recently discovered in the United States in a pig with influenza-like symptoms (1). So far, IDV or IDV antibodies have been detected in the United States, Mexico, France, Italy, China, and Japan, in healthy or sick cattle and pigs that had respiratory signs (1-6) (Figure 1). The pathogenesis and transmission of this virus are not fully understood, but recent experimental infection of calves showed that IDV can cause moderate respiratory disease (7) and that the virus is related to the bovine respiratory disease complex (2), which is a disease with very large economic costs and public health impact. The ability of IDV to replicate in ferrets, the animal model of choice for studying influenza virus in humans (1), and in guinea pigs ( 8 ) indicates that IDV might have a wider

Author affiliations: Interactions Hôtes Agents Pathogènes, Université de Toulouse, INRA, ENVT, Toulouse, France (E. Salem, J. Oliva, G. Meyer, M.F. Ducatez); International Livestock Research Institute, Nairobi, Kenya (E.A.J. Cook, D. Muloi, E.M. Fèvre); Institut Agronomique et Vétérinaire Hassan II, Rabat, Morocco (H.A. Lbacha, S. Alali, Z. Zouagui); Laboratoire Vétérinaire de Lomé, Lomé, Togo (F. Awoume); Laboratoire de Diagnostic Vétérinaire et de Sérosurveillance, Parakou, Benin (G.L. Aplogan); LANADA Central Laboratory for Animal Diseases, Bingerville, Côte d'Ivoire (E.C. Hymann); University of Edinburgh Centre for Immunity, Infection, and Evolution, Edinburgh, Scotland, UK (D. Muloi); St. Louis Zoo Institute for Conservation Medicine, St. Louis, Missouri, USA (S.L. Deem); University of Liverpool Institute of Infection and Global Health, England, UK (E.M. Fèvre)

DOI: https://doi.org/10.3201/eid2309.170342 host range than currently expected and that humans may be susceptible to infection. In addition to swine and cattle, anti-IDV antibodies have been detected in goats and sheep (9). We conducted a study to assess the putative IDV circulation in Africa.

\section{The Study}

During 1991-2015, a total of 2,083 serum samples were collected from cattle, swine, small ruminants, and dromedary camels in Morocco $(n=200)$, Togo $(n=540)$, Côte d'Ivoire $(n=203)$, Benin $(n=308)$, and Kenya $(n=1,231)$ (Table 1). We screened these samples by hemagglutination inhibition (HI) and microneutralization (MN) assays as described in the World Health Organization Manual for the Laboratory Diagnosis and Virological Surveillance of Influenza (10) (online Technical Appendix, https://wwwnc. cdc.gov/EID/article/23/9/17-0342-Techapp1.pdf).

Our results show that IDV has been circulating in North and West Africa since at least 2012, as shown by the antibodies detected in cattle in Morocco (from 2012 to 2015), cattle in Benin and Togo (as of 2014), and small ruminants in Togo (as of 2013) (Table 1; Figure 1). HI titers were low in ruminants, ranging $10-80$ in West Africa and 10-640 in Morocco; geometric mean titers ranged 13-42 (Figure 2; HI antigen was D/bovine/Nebraska/9-5/2012). More recently, serum samples were more likely to be positive for IDV antibodies, as shown by a higher seroprevalence over time in cattle samples from Morocco and Togo $(23 \%, 41 \%$, and $42 \%$ seroprevalence in Morocco in 2013, 2014, and 2015, respectively; 0 and $21 \%$ seroprevalence in Togo in 2009 and 2015, respectively). None of the samples from swine or cattle in Côte d'Ivoire or small ruminants in Benin were IDV antibodypositive (Table 1; Figure 1).

To confirm our results, we tested samples from the Moroccan cohort ( $\mathrm{n}=200$ cattle samples; Table 1$)$ by using $\mathrm{MN}$ and $\mathrm{HI}$ with $\mathrm{D} /$ bovine/France/5920/2014 as antigen. These assays were in substantial agreement with a Cohen kappa coefficient $(\kappa)$ of 0.647 (95\% CI 0.541-0.753); $68 \%$ of the MN-positive samples were also positive by HI (Table 2). The agreement between HI assays with D/bovine/Nebraska/9-5/2012 and D/bovine/France/5920/2014 showed even more substantial agreement $(\kappa=0.796,95 \%$ CI 0.709-0.883). All samples from Benin and Togo that 


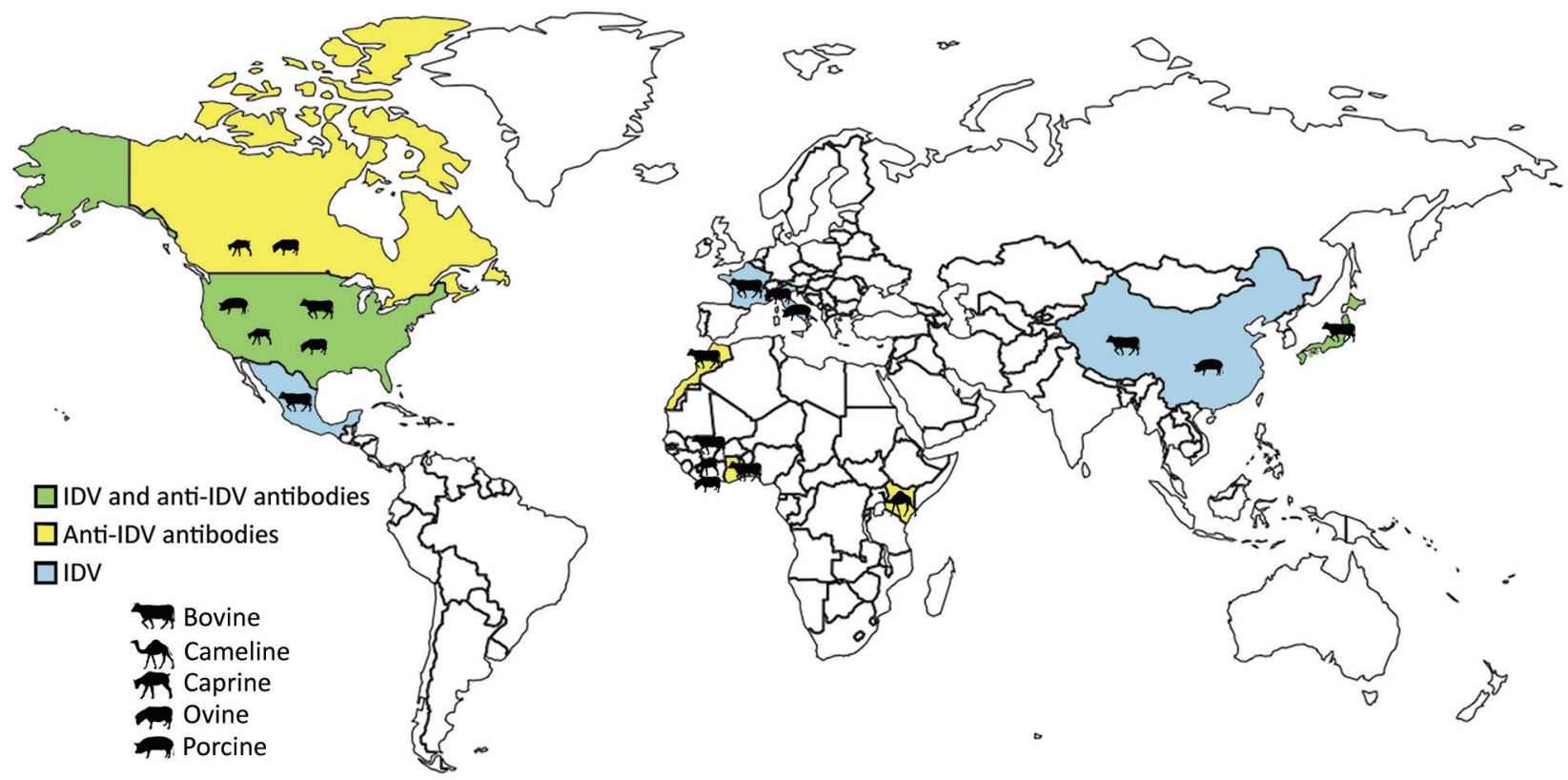

Figure 1. Locations where IDV or IDV antibodies had been detected as of April 2017. Species from which virus or antibodies were detected are indicated. IDV, influenza D virus.

were positive by $\mathrm{HI}$ using $\mathrm{D} /$ bovine/Nebraska/9-5/2012 were tested with D/bovine/France/5920/2014 and showed consistent positive results.

We then assessed IDV circulation in Kenya. None of the cattle serum samples were positive (Table 1). We first tested the 2015 camel samples from Kenya by using $\mathrm{HI}$ with both IDV antigens; testing with $\mathrm{D} /$ bovine/ $\mathrm{Ne}$ braska/9-5/2012 showed 99\% seroprevalence and with
D/bovine/France/5920/2014 100\% seroprevalence (Table 1; data not shown). HI titers were higher than those observed with ruminant samples from North and West Africa $(20 \leq \mathrm{HI}$ titers $\leq 640$, geometric mean titer $=150$; Figure 2). When tested by using C/Victoria/1/11, the seroprevalence was $94 \%(10 \leq \mathrm{HI}$ titers $\leq 320$, geometric mean titer $=38$ ), suggesting ICV/IDV cross-reactivity. The samples were therefore adsorbed on 4 hemagglutination

\begin{tabular}{|c|c|c|c|c|c|}
\hline \multirow[b]{2}{*}{ Country } & \multicolumn{5}{|c|}{ Species } \\
\hline & Cattle & Swine & Sheep & Goats & Camels \\
\hline \multicolumn{6}{|l|}{ Benin } \\
\hline$\%$ Positive & 1.9 & ND & 0 & 0 & ND \\
\hline No. samples & 207 [1] & ND & 67 & 34 & ND \\
\hline Years & 2012,2014 & ND & 2013-2014 & $2013-2014$ & $\mathrm{ND}$ \\
\hline \multicolumn{6}{|l|}{ Togo } \\
\hline$\%$ Positive & 10.4 & ND & 2.2 & 1.4 & ND \\
\hline No. samples & 201 [10] & ND & 135 [2] & $205[0]$ & ND \\
\hline Years & 2009,2015 & ND & 2013 & 2013 & ND \\
\hline \multicolumn{6}{|l|}{ Côte d'Ivoire } \\
\hline$\%$ Positive & 0 & 0 & ND & ND & ND \\
\hline No. samples & 100 & 103 & ND & ND & ND \\
\hline Years & $1991-2013$ & 2013 & ND & ND & ND \\
\hline \multicolumn{6}{|l|}{ Morocco } \\
\hline$\%$ Positive & $35 \%$ & ND & ND & ND & ND \\
\hline No. samples & 200 [32] & ND & ND & ND & ND \\
\hline Years & $2012-2015$ & ND & ND & ND & ND \\
\hline \multicolumn{6}{|l|}{ Kenya } \\
\hline$\%$ Positive & 0 & ND & ND & ND & $99 \dagger$ \\
\hline No. samples & 938 & ND & ND & ND & 293 [287] \\
\hline Years & $2010-2012$ & ND & ND & ND & 2015 \\
\hline
\end{tabular}

*A total of 2,083 serum samples were collected. Seroprevalence defined by HI titers $\geq 10$ against D/bovine/Nebraska/9-5/2012. Numbers in brackets indicate animals with $\mathrm{HI}$ titers $\geq 40$. $\mathrm{HI}$, hemagglutination inhibition; ND, not done.

†No preadsorption on influenza $\mathrm{C}$ virus cross-reactivity likely. 

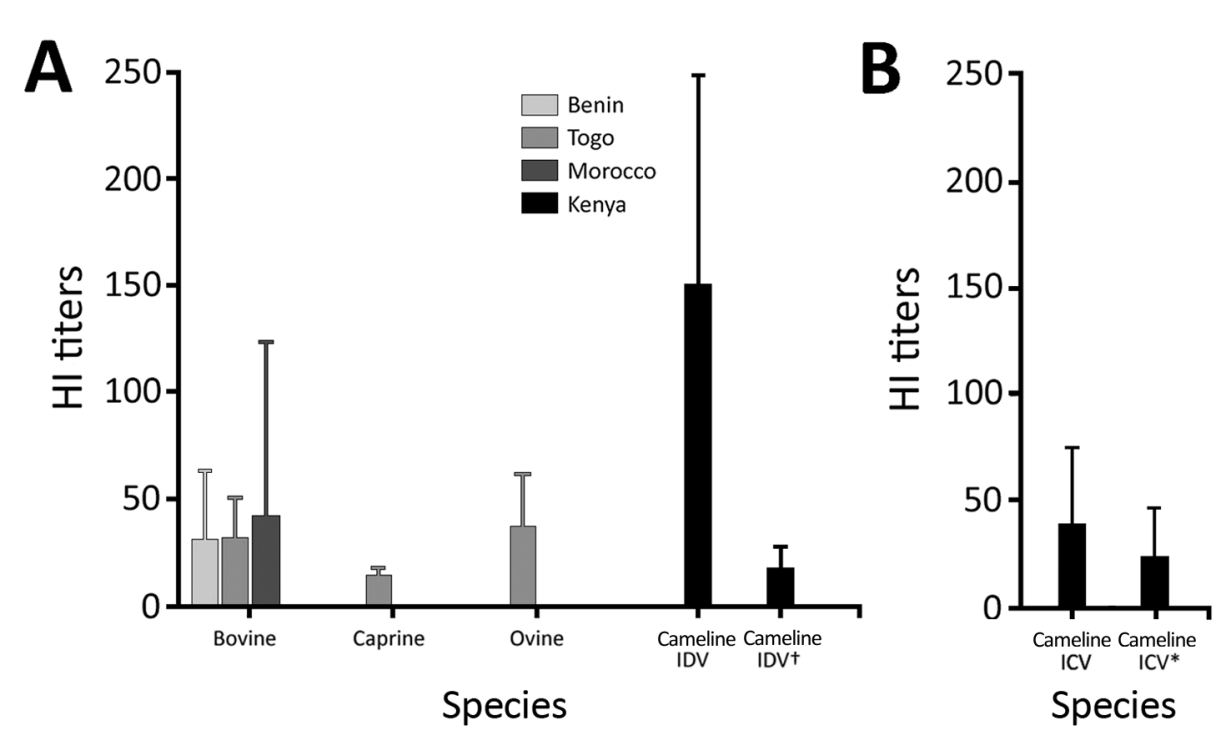

Figure 2. HI titers for ICV and IDV in serum samples from animals in Africa, by country. A) Titers against IDV by using D/bovine/ Nebraska/9-5/2012 as antigen. B) Titers against ICV by using C/Victoria/1/2011 as antigen. Histograms represent mean $\mathrm{HI}$ titers per country and species as indicated on the $x$-axis. Error bars indicate SEM. *Post-IDV adsorption; †post-ICV adsorption. $\mathrm{HI}$, hemagglutination inhibition; ICV, influenza C virus; IDV, influenza D virus.

units of $\mathrm{C} /$ Victoria/1/11 and hemadsorbed before being retested in $\mathrm{HI}$ with $\mathrm{D} /$ bovine/Nebraska/9-5/2012 and vice versa (all 293 samples were retested for IDV antibodies after preadsorption with ICV; 85 samples were preadsorbed on IDV and retested for ICV antibodies). Seroprevalences were $8.2 \%$ for IDV and $10.6 \%$ for ICV. All but 1 of the samples that were positive for IDV antibodies without ICV preadsorption lost $>2 \log _{2}(>4$ fold decrease in titer) in HI titer once adsorbed on ICV, suggesting these samples had anti-ICV rather than antiIDV antibodies. The picture was less clear for the reverse experiment: $11 \%$ of the IDV preadsorbed samples lost $>2 \log _{2}$ in titer (false ICV antibodies positive); $9 \%$ stayed within the 4-fold range (true positives); and the initial ICV antibody titer of the remaining $80 \%$ was too low (HI titers of 10 or 20) to determine a status postIDV adsorption. Taken together, our serology results on camel samples show that almost all the animals had either anti-IDV or ICV antibodies, that there is crossreactivity in camels between the 2 viruses, and that $9 \%$ of the tested samples had anti-ICV antibodies. Camels could therefore be a newly discovered host for ICV, and possibly for IDV. IDV/ICV cross-reactivity was ruled out for bovine samples after a cohort from France was preadsorbed the same way and retested in IDV HI without any change in HI titers (data not shown). Detection of antibodies against IDV in ruminants in Africa raises the question of the virus origin and transmission route. Although the virus has already been reported on 3 continents, the ruminant import/export from/to North and West Africa is limited (e.g., 21,000 cattle imported from Europe to Morocco, no exportations reported; no import or export of cattle reported to or from Togo or Benin; data for North and West Africa, 2013 [11]). Seroprevalences we calculated may also be underestimated because our HI assay was less sensitive than our MN assay (Table 2); numerous freezing and thawing cycles may have altered the samples; and our low titers in ruminants might have been caused by the circulation of a different IDV lineage in Africa or to the unique structure of camel antibodies, which are devoid of light chains and CH1 domain.

Although influenza A viruses are known to have nonhuman maintenance hosts, little is known on the host tropism of IDV and ICV. So far cattle, swine, sheep, goats, guinea pigs, and ferrets have been reported to be susceptible to IDV infection $(1,6,8,9)$ and swine, dogs, and humans to ICV infections $(12,13)$. Many aspects of camel health had not been studied before the emergence of Middle East respiratory syndrome coronavirus (14), but camels had been reported susceptible to influenza $\mathrm{A}(\mathrm{H} 1 \mathrm{~N} 1)$ on 1 occasion (15). Our data suggest that ICV and IDV have a wide host tropism and that further investigations on host tropism and on ICV and IDV circulation in camels are warranted.

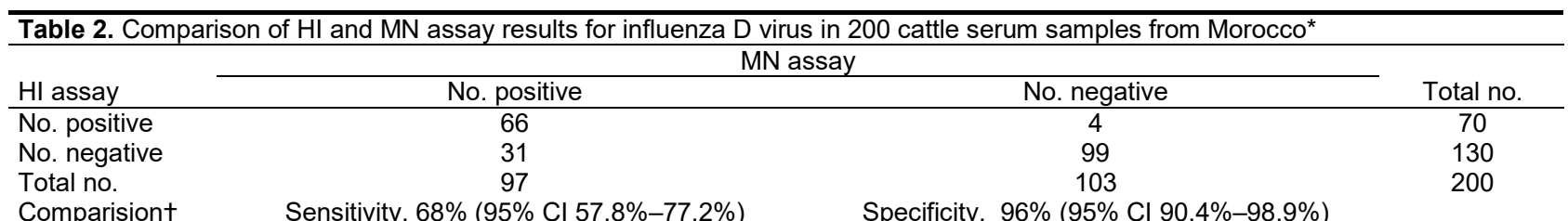

*By using D/bovine/France/5920/2014 as antigen. Titers $\geq 10$ were considered positive. HI, hemagglutination inhibition; MN, microneutralization. †For $\mathrm{HI}$ as compared with MN. 


\section{Conclusions}

Our results show that IDV is circulating in Africa. This virus has a wide host tropism because cattle, swine, small ruminants, and likely dromedary camels seem susceptible to IDV infection. In addition, we show that camels in Kenya are positive for ICV antibodies, suggesting that this virus also has a wider host range than previously thought. Further studies are warranted to clarify the cross-reactivity of the 2 viruses in serologic assays, to determine which IDV lineages circulate in Africa, and to assess whether ICV alone or both ICV and IDV may infect camels.

\section{Acknowledgments}

We thank Ben Hause for providing D/bovine/Nebraska/9-5/2012 and Richard Webby and Evelyn Stigger for providing C/ Victoria/1/2011, as well as all 3 for fruitful discussions. We also thank Maia Ticomb, Vincent Cantaloube-Ferrieu, Michele Marino, Angélique Teillaud, Josianne Loupias, and Brigitte Peralta for excellent technical assistance.

This work was supported by the 'FLUD' grant of the Agence Nationale pour la Recherche, the 'RESPICARE' grant of the Institut Carnot Santé Animale (ICSA), and by the French Ministry of Agriculture. E.S. is supported by a $\mathrm{PhD}$ scholarship of the Lebanese University.

Mr. Salem is a PhD student at the Interactions Hôtes Agents Pathogènes in Toulouse. His research interests include bovine respiratory viruses and their interactions.

\section{References}

1. Hause BM, Ducatez M, Collin EA, Ran Z, Liu R, Sheng Z, et al. Isolation of a novel swine influenza virus from Oklahoma in 2011 which is distantly related to human influenza $\mathrm{C}$ viruses. PLoS Pathog. 2013;9:e1003176. http://dx.doi.org/10.1371/journal.ppat.1003176

2. Mitra N, Cernicchiaro N, Torres S, Li F, Hause BM. Metagenomic characterization of the virome associated with bovine respiratory disease in feedlot cattle identified novel viruses and suggests an etiologic role for influenza D virus. J Gen Virol. 2016;97:1771-84. http://dx.doi.org/10.1099/jgv.0.000492

3. Murakami S, Endoh M, Kobayashi T, Takenaka-Uema A, Chambers JK, Uchida K, et al. Influenza D virus infection in herd of cattle, Japan. Emerg Infect Dis. 2016;22:1517-9. http://dx.doi.org/10.3201/eid2208.160362
4. Ducatez MF, Pelletier C, Meyer G. Influenza D virus in cattle, France, 2011-2014. Emerg Infect Dis. 2015;21:368-71. http://dx.doi.org/10.3201/eid2102.141449

5. Jiang W-M, Wang S-C, Peng C, Yu J-M, Zhuang Q-Y, Hou G-Y, et al. Identification of a potential novel type of influenza virus in bovine in China. Virus Genes. 2014;49:493-6. http://dx.doi.org/10.1007/s11262-014-1107-3

6. Chiapponi C, Faccini S, De Mattia A, Baioni L, Barbieri I, Rosignoli C, et al. Detection of influenza D virus among swine and cattle, Italy. Emerg Infect Dis. 2016;22:352-4. http://dx.doi.org/10.3201/eid2202.151439

7. Ferguson L, Olivier AK, Genova S, Epperson WB, Smith DR, Schneider L, et al. Pathogenesis of influenza D virus in cattle. J Virol. 2016;90:5636-42. http://dx.doi.org/10.1128/JVI.03122-15

8. Sreenivasan C, Thomas M, Sheng Z, Hause BM, Collin EA, Knudsen DEB, et al. Replication and transmission of the novel bovine influenza D virus in a guinea pig model. J Virol. 2015;89:11990-2001. http://dx.doi.org/10.1128/JVI.01630-15

9. Quast M, Sreenivasan C, Sexton G, Nedland H, Singrey A, Fawcett L, et al. Serological evidence for the presence of influenza D virus in small ruminants. Vet Microbiol. 2015;180:281-5. http://dx.doi.org/10.1016/j.vetmic.2015.09.005

10. World Health Organization. Manual for the laboratory diagnosis and virological surveillance of influenza. Geneva: The Organization; 2011.

11. Food and Agriculture Organization of the United Nations. FAOSTAT [cited 2017 Mar 3]. http://www.fao.org/faostat/ en/\#data/TA

12. Kimura H, Abiko C, Peng G, Muraki Y, Sugawara K, Hongo S, et al. Interspecies transmission of influenza $\mathrm{C}$ virus between humans and pigs. Virus Res. 1997;48:71-9. http://dx.doi.org/10.1016/ S0168-1702(96)01427-X

13. Ohwada K, Kitame F, Sugawara K, Nishimura H, Homma M, Nakamura K. Distribution of the antibody to influenza $\mathrm{C}$ virus in dogs and pigs in Yamagata Prefecture, Japan. Microbiol Immunol. 1987;31:1173-80. http://dx.doi.org/10.1111/j.1348-0421.1987. tb01351.x

14. Deem SL, Fèvre EM, Kinnaird M, Browne AS, Muloi D, Godeke GJ, et al. Serological evidence of MERS-CoV antibodies in dromedary camels (Camelus dromedaries) in Laikipia County, Kenya. PLoS One. 2015;10:e0140125. http://dx.doi.org/10.1371/ journal.pone. 0140125

15. Yamnikova SS, Mandler J, Bekh-Ochir ZH, Dachtzeren P, Ludwig S, Lvov DK, et al. A reassortant H1N1 influenza A virus caused fatal epizootics among camels in Mongolia. Virology. 1993;197:558-63. http://dx.doi.org/10.1006/viro.1993.1629

Address for correspondence: Mariette F. Ducatez, Interactions Hôtes Agents Pathogènes, Université de Toulouse, INRA, ENVT, 23 Chemin des Capelles, 31076 Toulouse, France; email: m.ducatez@envt.fr 